\section{COMMUNICATION AND CUSTOMER RETENTION: A CASE OF AN ACCOUNTING ORGANISATION}

\section{LeWen Tran and Dr Ehtasham Ghaur}

\section{INTRODUCTION AND AIM}

One of the key factors for the success of any business is client retention. The purpose of this research is to explore an organisation's use of communication to engage their clientele and its effects on client retention. This is determined through the client's continued use of provided services. The organisation in this research is $X Y$, a business advisory company based in New Zealand. Their services include: accounting, business systems solutions, human resources, payroll, taxation, wealth management and training. In 2018, XY had four partners and 50 staff in Dunedin, and 10 staff employed overseas, focused in all areas of business advice. They appreciate the role their staff play in helping their clients and communities

The mission statement for $X Y$ aims to provide services that surpass the expectations of their clients and to help those clients become more profitable. To achieve this aim, the staff and clients have to communicate with one another to gain an understanding of the client's needs and thus tailor services to the best of their ability. When this communication is achieved the satisfied client will likely continue using the offered services. XY would like to know if any improvements could be made to enhance the engagement between themselves and their clients.

The aim of this project is to gain an understanding of the impact client engagement has on client retention at $X Y$ The catalyst for this research was to discover if $X Y$ engaged their clients enough in terms of contact frequency and if the selected methods of communication were adequate for their client base.

\section{RESEARCH QUESTION:}

How does current engagement levels of retention influence client retention at XY?

In particular:

- What engagement methods are being used by $X Y$ to engage their clients?

- How satisfied are PH's clients with the amount of engagement occurring between the two parties?

- What relationship exists between the amount of engagement from $X Y$ and client retention?

The engagement method refers to the communication tools used between the client and the business, for example, phone, face-to-face and email.
The themes of this literature review are client engagement, communication methods, customer relationship Westionnaire and interview questions.

\section{Client engagement}

The term client engagement does not have a definition that all researchers can agree on.Vivek, Beatty, and Morgan (20 I2), define client engagement as the degree to which an individual participates and connects to activities that an organisation offers, initiated by the customer or the business. Jones $(2010)$ views it as the quality of interactions and delivery of relevant products and services that are of benefit to the customer. Engaged customers are those that are loyal to the business and recommend a company's products and services to others according to Roberts and Alpert (20I0). Engagement has to provide value, be appropriate and achieve the needs and goals of the customer. Once these are achieved, the customer will be satisfied (Jones, 2010).

Roberts et al. (2010) described customer engagement as a five-level process. Level I, the customer uses the product or service offered. Level 2, the customer is loyal to the product or service and continues to use it. Level 3 , the customer uses other products or services provided by the company. Level 4 , the customer endorses the products or services to others when given the chance. Level 5 , the customer promotes the product or service at every opportunity (Roberts et al., 2010). Customers that are actively involved in a service process show higher satisfaction levels and are considered more loyal than other customers (Rehnen, Bartsch, Kull, \& Meyer, 2017). Marketing is a key player in engaging clients. It brings awareness of other services or products that the business can provide, thus affecting what they purchase (Roberts et al., 2010).

There is very little research around how much engagement a business providing financial advice to customers should have. The level of engagement is inportant as this could affect the type of relationship a business wants to form with their clients. The less contact the business has, the less involved the client is; the more distant they feel. Increasing the amount of communication between two parties can result in an improved relationship, as there are more opportunities to build trust (Hannan, Suharjo, Kirbrandoko, \& Nurmalina, 2017). A research conducted, involving I,099 clients of 129 accounting firms, found that the clients wanted the accounting firms to involve them more (Nixon, 20I I). The clients wanted more knowledge and information in advance before issues could arise. Regular communication with clients increases the opportunities for the firm to build stronger relationships with those clients. Effective communication provides a further benefit as clients feel like they are able to openly express any concerns they may have (Nixon, 20I ).

For this research, the term client engagement will refer to the use of communication to involve clients in a business. The aim of this engagement is to form a relationship that is mutually beneficial for both parties.

\section{Communication methods}

Communication is defined as a process by which two parties can exchange information through a system, whether it be a sign or a behaviour. This process is the main way a business can engage their clients. The interaction model of communication is a model that shows the communication between the sender and the receiver who are participants of the interaction (Tripathy, 2018). The sender is a person who is trying to communicate a message to the receiver The receiver receives the message and tries to process what is being communicated to them. The sender encodes a message that the receiver has to decode. This communication is transferred via a communication channel. Communication channels are the different methods that businesses use to communicate with its target market (Danaher \& Rossiter, 201 I). There are a variety of methods available, but each method conveys the message in a different way (Sinha, 2012). 
According to the media richness theory, there are two main types of media, a rich media and a lean media (Aliukhadar, \& Senecal, 2017). A rich media is used to communicate information that can be found as confusing or hard to explain in a short amount of time (Stone, 2012). Lean media is used to explain information that is not confusing and understood by any party they are communicating with (Kishi, 2008). The richness of media has an effect on the clients' choice of communication channel, quality of decisions and the clients' satisfaction (Lee, Kozar, \& Larson, 2009). Television advertisements and radio are used as a form of lean media, as it reaches a range of people that can understand the information. Face-to-face and telephone communication are the richest forms of media allowing for immediate feedback, where the other party can clarify the point they are trying to convey (Stone 20 I2).Written forms of communication have a varied amount of richness (Stone, $201 \mathrm{I}$ ). Letters that are specifically written for an individual are richer than one written for a general group of people. Lean media does not allow for immediate feedback or verbal and non-verbal cues that a richer communication method may have (Stone, 20 I2).

Receivers of communication require a gain of information, knowledge and understanding. From previous research, it has been found that communication is only effective if the communication method being used is one that the receiver of the message prefers (Danaher \& Rossiter, 20II). Kiwis Count (2010), a New Zealand (NZ) State Services Commission, conducted a questionnaire to seek how NZ citizens preferred to deal with public services Their research found that NZ citizens preferred using face-to-face contact followed closely by phone calls and emails. Businesses are continually developing the way they communicate and engage with their clients. Businesses can form relationships with their clients by communicating with them appropriately. Accounting firms often use newsletters to engage their clients, as they typically find this form of communication shows the company's expertise and knowledge, while also helping to promote other potential services the business could provide (McColl-Kennedy Sweeney, Soutar \& Amonini, 2008; Cameron \& Reeb, 2008)

\section{Customer Relationship Management}

Customer relationship management is viewed as the process, thought of development and management of relationships with customers (Laketa, Sander, Laketa, \& Misic, 2015). Business cannot survive without customers therefore a firm's sustainable existence depends on creating and retaini the customers. Retaining clients requers therefore a to have processes in pace to repeat business with the organisation (Nixon, 2011). Forming a good a business to he processes in place to repeat businss wh the organisation (Nixon, 2011). Forming a good Chen 2008 ) Their (Sirip, 2008). Their goal is to attract and keep these customers who wil become the organisation's true customers (Siriprasoetsin, Tuansuk, \& Vongprasert, 2011). True customers are those who become loyl's to the business. Atracting these customers occurs through the management of customernelated activities, like sales, marketing service and support. These task aim to find and retain the more proftable and help the less proftable customers (Wang, 2012). There is limited research around the area of customer relationship management in the profession service industry, especially the business advisory sector (Walsh, \& Gordon, 20 I0).

Businesses should focus on forming relationships with their customers rather than just focusing on the transactions that occur between them (Zeithaml, Bitner, \& Dwayne, 2009; Akbari, Kazemi \& Haddadi, 2016). There are many businesses, such as accounting firms that offer the same types of services This means they all compete for the sany customer mas $B$ Biht

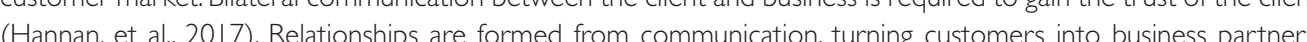
(Hannan, et al, 2017). Relationships are formed from communication, tuning customess into business partners. Through client engagement, the business is motivated to keep improving the quality of their services in order to retain these 'partners' (Hannan, et al, 2017: Nixon, 2011).

\section{Client retention}

Businesses providing products or services intend to expand and retain their customers. In the financial services sector, gaining a new customer is thought to cost the business up to 14 times more than retaining a current one (Jones, 2010). Keiningham and Aksoy (2009) commented that approximately 20 percent of customers are profitable, 20 percent will cost money to keep and 60 percent will pay for themselves while returning margina revenue. Retaining clients will help a business become more profitable. When clients and the business form a good relationship, the client is inclined to spend more, increasing the business' profitability (Hayes, 2008). Jones (2010) suggests that organisations providing financial services should aim to keep their profitable customers, help their marginally unprofitable customers to become more profitable, and decrease the amount of resources spent on the costly ones. When clients become loyal to a business they will continue using the services provided, resulting in a retained client (Roberts \& Alpert, 2010). The engagement between businesses and clients does not always lead to a loyal client (Jones, 2010).

Customer loyalty is the intention of an individual repurchasing products and services provided by a business (Pi \& Huang, 201 I).This concept is important to businesses as loyalty results in clients willing to spend more, increasing the businesses revenue and effecting client retention (Hannan et al., 2017). Loyalty has two aspects to it, behavioural and attitudinal. Behavioural loyalty is shown through the client's actions, which includes repeat of purchases, prone to being attracted to competitors in the market and engaging in word-of mouth marketing for businesses (Szczepanska \& Gawron, 20I I). Attitudinal loyalty is the client's emotional commitment which is measured through repurchase intentions (Brunner, Stocklin \& Opwis, 2008). There are different factors that can affect the loyalty of clients

For clients to become loyal to a product or service they have to experience it first. Customer satisfaction is referred to as how content the customer thinks they are with the product or service they have purchased (Stan, Caemmerer, \& Cattn-lallet, 2013; Kaura, Prasad, \& Sharma, 2015). The quality of services provided is important in making clients satisfied. If the quality of service they received meets the clients' expectation, they will likely be satisfied with the service and continue using the business (layawardhena, 2010). Satisfaction will also result in recommendations of the products and services to their friends and associates, expanding the businesses customer base through word of mouth (Bose \& Rao, 201 I; Akbari et al., 2016).

Companies may have reward programs in place to retain their clients. Some banks are increasingly dissatisfied with their loyalty programs as it is expensive to set up and run. Well managed programs increase customer satisfaction, helping the business gain and retain good customers (Jones, 2010 ). It was found that customers who were able to redeem rewards from the program were more satisfied than those who could not (Jones, 20I0). In the banking sector in India, service quality, convenience and the fairness of price were important loyalty where multiple businesses were offering the same services (Kaura, et al., 2015).

\section{RESEARCH METHODS}

The goal of the research was to understand $X Y$ engagement with their clients. To achieve this objective, the research employed an action research approach to explore the influence of client engagement on client retention at XY. Action research approaches require a research process on the particular area of interest for the entity (Kumar, 201I). The results were evaluated to develop processes which improve the organisation to become more efficient (Eikeland, 20 I2).The research tools utilised in this study were a questionnaire and interviews. These two techniques were conducted simultaneously using a mixed research method. A concurrent mixed research method is the use of both quantitative and qualitative elements in a research effort at the same time (Schoonenboom \& Johnson, 20 I7). Using multiple research methods allows for increased validity of the results collected, also known as triangulation when two or more methods target one phenomenon (Grafton, Lillis, \& Mahama, 20I I).

Triangulation in a research study allows for the convergence of results collected through different research methods studying the same research issue. This approach is likelier to result in reliable, credible and confirmable information (Abdalla, Oliverira, Azevedo \& Gonzalez, 2018; Bailey, 2018). Brannen (2005) states that triangulation allows: corroboration- getting the same results using different methods, elaboration- results giving examples of why 
something is occurring in the situation, complementarity- using different research methods emphasises an aspect during research, and contradiction- results from different methods reveal (....and might partially) cause opposing outcomes. Using questionnaires and interviews in this study meant that the data collected were very likely to be independent of each other.

\section{Questionnaire}

The questionnaire consisted mainly of closed-ended questions with one open-ended, and took approximately five to ten minutes to complete. Having an online questionnaire in this research helped save resources such as time and financial costs, while giving access to a larger audience (Kumar, 20I I). Kumar also states that an online questionnaire enables greater anonymity for the respondents, giving rise to more honest answers, as they feel they can answer freely

At the time this research was undertaken, the level of engagement directly affected the clients using the services provided by $X Y$. Therefore, the online questionnaire was intended for this population. The questionnaire was designed to gain an understanding of the usual amount of interaction, what interaction method the clients preferred and if they planned to use the services again. Some of the questions formulated for the questionnaire were based on previous studies on customer service and its effect on client retention (Keiningham, Cooil, Aksoy, Andreassen, \& Weiner, 2007). This was so that results were more credible. XY staff, Otago Polytechnic supervisors and trusted significant-others reviewed and edited the questionnaire to ensure that the questions were understandable. An ordinal scale of continuous measures and Likert questions were used to gain an understanding of how clients perceived the engagement and communication channels used by XY. A copy of the questionnaire can be found in Appendix A.

One-hundred-and-thirty main clients were randomly selected using a random number generator to complete the questionnaire. All questionnaires were sent from XY's marketing email.

Since the researcher intended to question the $X Y$ 's clients, a $X Y$ ' staff member was required to help facilitate in sending the questionnaires to the clients (Lavrakas, 2008). The restriction on the number of respondents is to follow the business' normal practice when distributing their own surveys. The online questionnaires were created and sen to participants by email using the marketing management system tool, m-sawy

\section{Interview}

To corroborate and triangulate the results from the questionnaire, a semi-structured interview approach was employed. The interview questions used were formed by the researcher with the aim to reflect the themes found in the literature reviewed. The interview questions were of an open-ended design to gain in-depth information on the topic. A copy of the questions used in the interview are presented in Appendix B. Each of the respondents were presented with an information sheet, via email, and a consent form, before the interview, regarding their participation. Respondents were assured of their anonymity and notified that by participating they would be agreeing to the information being used for research purposes. The researcher then made appointments with each agreeing to the information being used for research pupo
of the managers using the Microsoft Outlook calendar.

Interviews were conducted with eight $\mathrm{PH}$ managers. These managers are responsible for communicating with the clients. Prompting questions were also used to encourage the interviewees to expand on their responses. Each interview took between 10 and 20 minutes to complete. The researcher asked the questions, took handwritten notes and transcribed the interview. A voice recording device was used to record the interviews so the researcher could review the responses and transcribe responses with more details.

\section{Limitations of research methods}

Limitations can affect the reliability and credibility of the results collected for the research. One overall limitation of the research was time, given the deadines for this piece of applied research This meant that the questions use of the resech was the rividity a cred used in the questionnaire and interviews may not have been adequately piloted, and thus refined, in a way to gain the
best responses.

The sample size was limited to I30 clients, as the organisation usually sends out I 30 surveys at any one time. A larger response rate could increase the validity of the results. The population size was further restricted as clients that had completed a Net Promoter Score (NPS) survey conducted by XY', at a similar time to the research that had completed a Net Promoter Score (NPS) survey conducted by $X Y$, at a similar time to the research (Nice or not they wanted to respond to the questionnaire (Wright, 2005).

The quality of responses, can be influenced by the relationship between the interviewee and the interviewer for example some of the interviewees can feel uncomfortable with expressing some of their opinions to the researcher (Kumar 2011) The limitation of time may have also afected the qualty of responses as these interviews were conducted during the work hours of the interviewees.

Interviewer bias is another limitation that may affect the conveyance and the interpretation of the interviewees' responses.

\section{RESULTS}

The aim of this research was to answer this research question 'How do current engagement levels influence client retention at XY?' In particular, what communication methods are being used by $X Y$ to engage clients, how satisfied are clients with the amount of engagement occurring between the two parties and, what relationship exists between the amount of engagement and client retention?

\section{Questionnaire Results}

As described above, a questionnaire was used to analyse the views of $X Y^{\prime}$ clients regarding engagement level, communication methods and re-engagement of $X Y^{\prime}$ services. In this study, questionnaires were sent to I 30 clients electronically. A total of 61 clients completed this survey, giving a response rate of $47 \%$. Data analysis only used the 42 clients (32\%) who responded to all questions apart from question thirteen as it was an open-ended question. The data were collated into numerical codes to conduct statistical analyses

As illustrated in Figure 1. 36\% $(n=15)$ of the respondents had used XY services for fifteen plus years. $7 \%(n=3)$ had used their services for eleven to fifteen years. Additionally, $26 \%(n=I)$ had used it for six to ten years while $31 \%$ $(n=13)$ have been $X Y$ clients for less than five years. 


\section{Segmentation of Respondents by Years with PH}

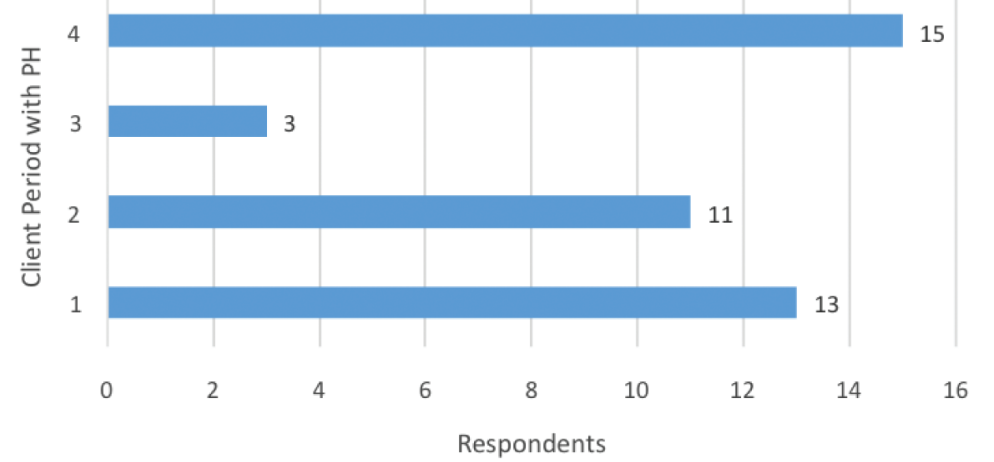

Figure I. Respondents' years using $X Y$ services

Number of Services Respondents Use

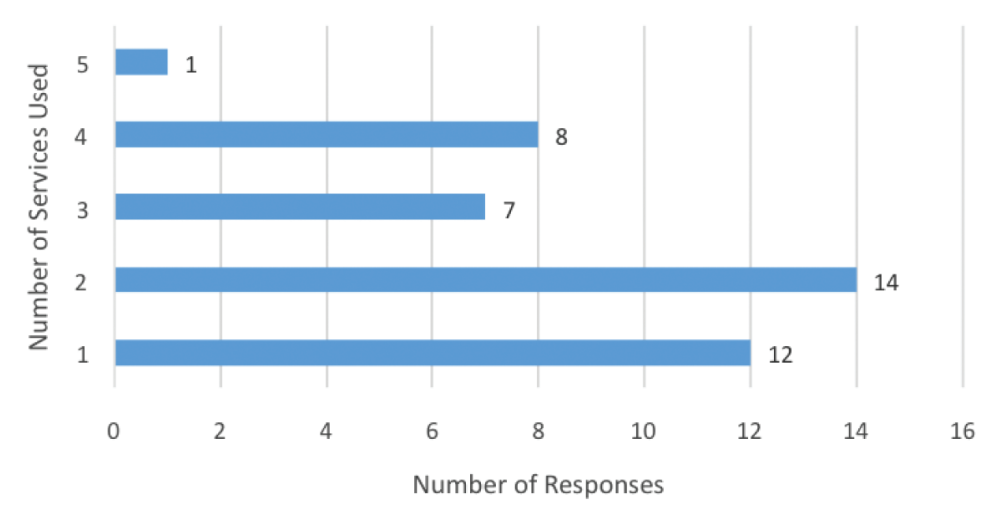

Figure 2. Number of services used by respondents

While some clients in this sample used as many as 4 or 5 services from $X Y$, over half of the client-sample use eithe one or two $X Y$ services. When breaking the data into segments, clients who had used $X Y$ for 0-10 years were using an average of around two services, while clients who had used them for || to $\mid 5$ plus years used an average of three services.

\begin{tabular}{|c|c|c|c|c|}
\hline Not important & Slightly Important & $\begin{array}{c}\text { Moderately } \\
\text { important }\end{array}$ & Important & Very Important \\
\hline 5 & 9 & 12 & 11 & 5 \\
\hline
\end{tabular}

\section{Frequency of responses:}

On average, replies indicated that communication frequency was moderately important when using the services (SD $=1.21$ ). $29 \%$ of the respondents reported that the frequency of communication was moderately important. Interestingly, it was found that $12 \%$ of the respondents did not find it important. This result was equal to the number of respondents that did find it very important. Respondents that had used XY' services for 0 to 10 years, found that the frequency of communication was only slightly important. In contrast, II to I 5 plus years respondents found

\begin{tabular}{|c|c|c|}
\hline & $\mathrm{XY}$ to Client & Client to $\mathrm{XY}$ \\
\hline Face-to-Face & Once a year & Once a year \\
\hline Phone call & Once a year & Once a quarter \\
\hline Email & Twice a month & Once a quarter \\
\hline Mailed letter & Once a year & Never \\
\hline Text message & Never & Never \\
\hline Video call & Never & Never \\
\hline
\end{tabular}

Two questions were used to find out how often the business and the clients contacted each other in one year These results are shown in Table I. The frequency of contact via face to face between the two parties was once a year. Clients tended to use the phone to contact $X Y$ more regularly, whereas it was found that $X Y$ would frequently contact the client, via email, twice a month compared to the client's once a quarter. $X Y$ sent mailed letters more than the client. The data also shows that both parties rarely used text messages or video calls.

More than half of the respondents (52\%) found that communication did not improve the quality of services provided by XY.Three respondents ( $7 \%$ ) found that communication improved the quality of service by a lot. When breaking it into segment by years with $X Y, 6$ to 15 plus years, communication improved the quality of services by a little, whereas 0 to 5 -year clients found that communication did not improve the service at all.

It was found that $48 \%$ of the respondents preferred using email. This was followed by phone calls, then face to face meetings, while $86 \%$ of the clients' least preferred method of contact was video calls. When breaking it into segments all respondents preferied connmuication through email Additionally 0 to 5 -yer respondents prefered face to face contact over a phone call.

Quality of communication: On a scale of one to five, $48 \%$ of the respondents found that the quality of communication was 'very understandable' The remaining 52\% found it to be between 'somewhat understandable' and 'understandable'.

Frequency of communication: More than half (67\%) of the respondents found that the frequency was 'just enough' There were $21 \%$ of respondents who found that the frequency was 'more than enough' and $5 \%$ found it 'too much'.

Service standards: $52 \%$ of the respondents found that the service standards were of a high quality, $33 \%$ responded that the service was of a good standard and I $2 \%$ found it to be of acceptable quality, while $64 \%$ of the respondents found that $X Y$ had met their expectations. There were equal numbers of respondents who found their expectations were somewhat met and those who reported that their expectations had been greatly exceeded. It was found that 25 (60\%) respondents said they would reuse the services. This is in comparison to one client who would definitely not reuse the services. 


\section{Interview Findings}

To achieve the aims of the study as mentioned above and triangulate the survey results, this study conducted interviews with eight managers at $X Y$. The intent of these interviews was to explore the respondents opinions on client engagement and its relation to client retention. To answer the research questions, managers were questioned on factors that drove customer retention.

All eight interviewees answered all the questions the researcher had posed (Appendix B). The data was collected to gain the opinions of what client engagement is and its effects on client retention.

\section{Client Engagement}

When the managers were asked what it meant to engage with clients, almost all replied with "communication". To them it meant getting to know the clients in a formal and informal manner. "It's about having a normal conversation with them not just business..." (Int D). The interviewees stated that by communicating, they were able to understand the clients' needs and deliver on what was communicated. This meant they were able to show "genuine interest" which allowed them to "personalise" their service. They also stated that engagement meant "having that relationship with the client" (Int E). This relationship, as stated by some of the managers, meant that the clients or the managers could "feel free" to ring or email each other when problems occurred. To Interviewee G, engagement meant they had to make the client feel "comfortable" enough to disclose their situation or information. This showed the they had to make the client feel "comfortable" enough to disco
managers that the clients trusted them to do the right thing.

Almost all the interviewees wanted to engage more with some of their clients. Interviewee $C$ stated that they had enough engagement with their clients. Some interviewees stated that judgements had to be made on how much engagement the clients wanted, "Everyone's different" (Int D). Interviewee E found it hard to engage with all their clients due to the limitation of time. Interviewee E referred to the "80/20 principle" to identify who required more engagement. Some interviewees stated that the engagement depended on if it would add value to the client.

\section{Communication Method}

Communication, as mentioned earlier, was important for the engagement of clients. The interviewees observed that by conversing with the clients they were able to learn more about the individual, helping to understand their needs. When interviewees were asked about the preference of communication method emails phone cals, and face to face meetings were highlighted as prefered methods. For some interviewees they found that when and face to

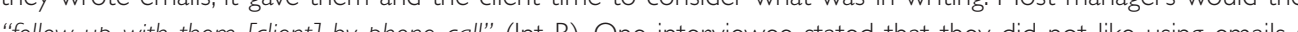
follow up wh the [Cling by phe coll (Int B). One interviewee stated that they did not hine using emails as they thought it was impersonal. Interviewee D found phone calls to be "convenient... on the phone it's all done and

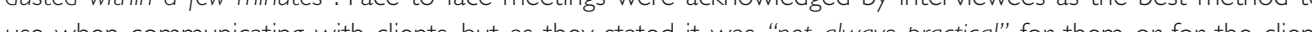
use when con (Int G). Interviewee D stated that face to face conmanication was "easier [as] you can read their body language" which let the manager know if the client understood. The interviewees stated that the communication methods used were based on the situation. It depended on if it was "of value," worth" and "of importance". Really important (we achieved by phone or email. "Talking on the phone is always about finding out what's going on" (Int G).

\section{Customer Relationship}

The word 'relationship' appeared 32 times in total from all the interviews, indicating how important this factor was to all of them. The interviewees mentioned that client relationships were formed through communication. Some interviewees built their relationship through monthly contact, resulting in the client referring colleagues to use the same services. "A good relationship I think like [Name]". They recommended us to these other ones and now they've come on board." (Int B). Interviewee E said, "The key to bu as regularlly] as possible ... I think any relationship that's strong [means] the chances of somebody actually breaking down that relationship is so much slimmer" It was identified by Interviewee $\mathrm{E}$ that a stronger relationship also meant that the client had more confidence in the manager Relationships would "fail if communication was inadequate" (Int $G$ ).

\section{Client Retention}

Six out of eight interviewees stated that having relationships with clients was a driving factor of client engagement. When interviewees were questioned if they thought the engagement levels affected the retention of clients, there ( found in Table 2.

\begin{tabular}{|c|c|c|c|}
\hline Interviewee A & Interviewee B & Interviewee C & Interviewee D \\
\hline $\begin{array}{l}\text { Relationship } \\
\text { Good service } \\
\text { Positive client } \\
\text { Perception of getting } \\
\text { value }\end{array}$ & $\begin{array}{l}\text { Good relationships } \\
\text { Monthly contact } \\
\text { More than one point of } \\
\text { contact }\end{array}$ & $\begin{array}{l}\text { Tends to be what drives } \\
\text { communication, and } \\
\text { attention } \\
\text { Service quality } \\
\text { Relationship }\end{array}$ & $\begin{array}{l}\text { Knowing the clients } \\
\text { Communicating and } \\
\text { responding } \\
\text { Available } \\
\text { Responding in timely } \\
\text { manner }\end{array}$ \\
\hline Interviewee E & Interviewee F & Interviewee G & Interviewee H \\
\hline $\begin{array}{l}\text { Good client service } \\
\text { Strong relationship } \\
\text { Delivering on what was } \\
\text { communicated }\end{array}$ & $\begin{array}{l}\text { Relationship } \\
\text { Perception of reliability } \\
\text { Trustworthy } \\
\text { Quality of advice } \\
\text { Being available }\end{array}$ & $\begin{array}{l}\text { Quality advice } \\
\text { Quality service } \\
\text { Responsive } \\
\text { Available } \\
\text { Timeliness } \\
\text { Be less generic }\end{array}$ & $\begin{array}{l}\text { Contact } \\
\text { Good service } \\
\text { Valued service } \\
\text { Make them feel valued }\end{array}$ \\
\hline
\end{tabular}

Table 2. Factors that drive customer retention

Some interviewees felt the level of engagement depended on the client. Some did not "necessarily want to engage with you". But it was identified by Interviewee F that this, "doesn't mean that we [the managers] shouldn't". Some of the interviewees noticed that "cost-based clients" were worried about the potential costs associated with contacting XY Interviewee A pointed out the managers should be clearer about costs that could be charged.

Other factors affecting the retention of clients include the provision of good advice and service quality. The managers provided these by "howing oood team", "being avelube" and "responsive" to calls and reducing tum-around times for client's work XY managers also try to improve sevice quality by person and reding and makn a service less "generi" for the cy me "genects for the clents through listening "conside clarity is key, "we as a firm are not the cheapest. We therefore must be on quality. If we're not delivering on quality then
[clients will] go somewhere cheaper." 


\section{DISCUSSION}

The aim of this research was to explore how the current client engagement levels may influence the client retention at XY.To achieve this aim, results were gathered through a questionnaire targeting $X Y$ clients and interviews with its managers The following sectic client engagement communication methods, client relationship management and client retention.

\section{Client Engagement}

The definition of client engagement is the use of communication to involve clients in a business forming a relationship that is mutually beneficial for both parties. In the findings, client engagement was about the communication, whether it be in an informal manner or a formal one. It was found that communication helped XY to better understand their clients, thus talloring the services for each individual. Merkl-Davies and Brennan (2017) stated that in accounting users of the financial statements had different skills and expertise, so it was important to be able to communicate with a range of clients.

It was reported that $67 \%$ of the respondents had experienced an adequate amount of communication with $X Y$. Interestingly, the staff at $X Y$ stated that they wanted to increase how much they engaged with their clients. They expressed that this engagement depended on each client and whether or not the interaction would add value to the individuals. The research found that the frequency and how well communication was understood aided the quality of service provided by the business. The results in the survey showed that clients with not enough contac, thought more communication could improve the quality of service they received. Clients who had an adequate amount of communication thought that more contact would not improve the quality of services. This relationship can be shown in Figure 3. This difference could be due to the belief that more frequent communication could lead to communication clarity, which would in turn improve the quality of the service received. This statement is thought to be true as the increased communication helps the service provider with gaining clearer information, therefore better tailoring of services, and improving of the overall quality of the service (Dabholkar, 20I5). Dadfar, Vrege, and Sedigheh (2013) found that clients appreciated the transfer of professional advice because they are not fully knowledgeable and are in need of getting assistance from the service provider to perform well.

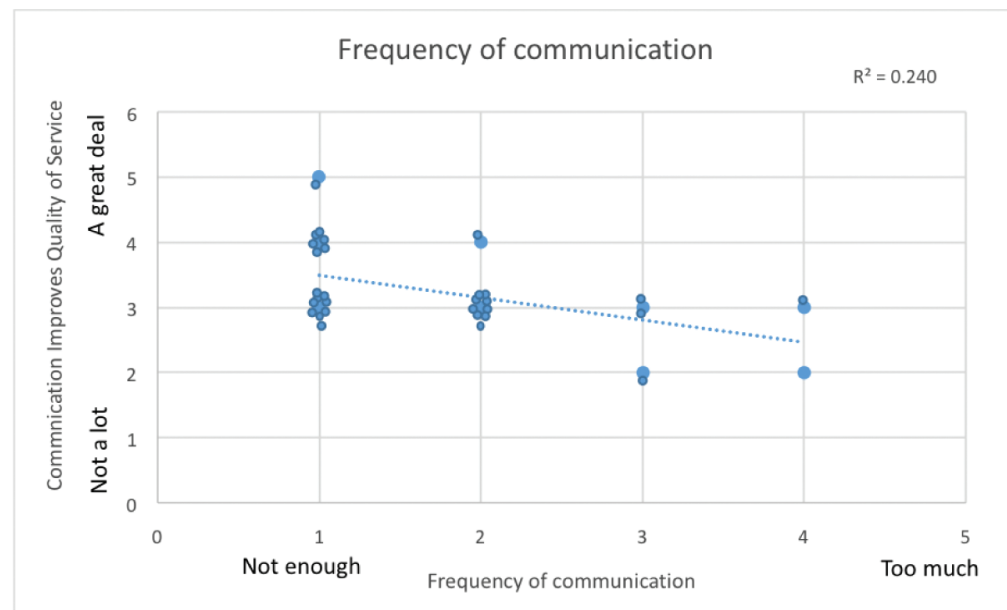

Figure 3. Frequency of communication and its relationship to the Improving the quality of service.
The research showed that the amount of communication was dependent on the individual client and the manager This result was supported by Schertzer, Schertzer, and Dwyer's (2013, p. 612) research. They also found that "performance of professional services was highly dependent on the interactions between service provider and client". The findings of the current research found that costs were a factor that had an influence on the amount of engagement clients wanted. As mentioned in the literature review, clients would look at the fairness of price when choosing services (Kaura, et al., 2015). Participants stated that the clarity of costs were required. The uncertainty of the costs could put off a client wanting to engage more with the business.

\section{Communication Method}

Clients and managers preferred engaging through the use of emails. Shrivastava (2012) stated that communicating through emails was becoming popular as it was efficient. Results showed that currently, both the client and XY staff contacted each other through email more frequently than any other method of communication. Some respondents in the interviews conveyed that they preferred emails, as it gave them time to consider the message when preparing it. It was also expressed that it was impersonal and inappropriate for some situations. Phone calls were the next preferred method of contact by clients and managers. This method of contact was found to be convenient, it allowed immediate feedback, so it was quicker to communicate the message to the other party. Communication through ace to face meetings wer preferred after phone calls as seen in the findings of this research. It was interesting that when clients who had used XY for five years and less preferred face to face meetings and the older clients preferred when clients $\mathrm{T}$ h phone contact. 作 client or the ker e

\section{Client Relationship Management}

As mentioned in the introduction, clients are important for all businesses to continue into the foreseeable future. Relationships were a key theme in the interviews, illustrating how important these are for retention of clients. It was expressed in an interview that without communication there would be no relationship. Managers stated, through having regular client contact, they were able to gain more clients for the business. Regular communication was the foundation for building stronger relationships, making it harder for clients to defect from the business, while also promoting word-of-mouth to gain new clients. The communication process allowed the staff at PH to form relationships with their clients which also resulted in trust in the staff (Hannan, et al., 2017). The managers believed the clients were more comfortable to contact the team if required. Garaniti, Pearce, and Stanton's (20II) research supports this finding as they found that communication deepens relationships, also encouraging self-disclosure.

\section{Client Retention}

In the literature review it was mentioned that clients that were retained were loyal to the business. This loyalty was achieved from their experience with the businesses' services (Stan et al, 2013). The results showed that a third of the respondents had been loyal to $X Y$, using the services provided for fifteen plus years. This result shows that the business is providing a good experience for these clients. As Jones' $(2010)$ study mentioned, the engagement between the two parties does not always mean the client remains loyal. It was found that clients that had used the services of $X Y$ for longer were using more services than those who hadn't This result shows the loyalty of the the services of $X Y$ for longer
clients (Roberts, et. Al., 2010).

The results of this study did not find any strong relationships between the methods of contact and client retention The results also did not show any particularly strong relationship about the amount of engagement and client retention. Rather, it was there was a weak positive correlation between the two factors. This suggests that the 
frequency of engagement does not directly affect the retention of clients. Instead it was found that the experience of service standard and meeting the expectations of the clients had slightly more influence on the retention of clients As mentioned above the frequency of communication was dependent on the individual clients. The frequency of communication was only moderately important to the client when using XY' services. Instead, the results show there are other factors that are important to the clients when deciding to re-engage in a business.

There were a range of factors found in the questionnaire and interviews that may also have an effect on the retention of clients.

Quality of service - The results found that the quality of communication had an effect on the perceived service quality. The service quality showed a stronger correlation between likelhood of reusing services compared to the frequency of communication. When some interviewees were questioned on the meaning of services qualty some quality also means completing services in a timely manner

Adding value - A few of the managers expressed that clients would leave $X Y$ if they do not see value being added to their business It was stated that clients needed to feel valued Trasorras. Weinstein and Abratt's (2009) research, indicated that value is perceived differently among clients, further explaining that businesses had to have a unique strategy to drive value

\section{LIMITATIONS}

This research was restricted due to the lack of previous research conducted on the amount of engagement business should have with their clients, especially in the field of accounting. This also had an impact on the design and quality of data collection techniques and analysis measures.

A major limitation of this research is having social desirability response bias. This is stated to be where the questionnaire and interview prompt respondents to have an inclination of presenting themselves in a favourable image (Van de Mortel, 2008). This can affect the validity of the findings as it can skew the data, possibly confounding or hiding the relationships between variables.

A limitation of this research was the timeframe. The limited time prevented in-depth analysis of the data collected, affecting the quality of the findings. Due to the limited time questionnaires and interviews were conducted at the same time. This resulted in missing the important factor of relationships in the questionnaire which was found from the interviews. This may have given the organisation a better insight on their clients.

This research was a small-scale study, this poses a threat to validity and also means that the findings may not be appropriate to be generalised to the whole population (Hackshaw, 2008). Increasing the sample size of respondents for the questionnaire would increase the validity of the findings. Having the time pressure also meant that survey responses were collected over a short period decreasing the response rate.

\section{CONCLUSION}

This research project focused on $X Y$, a business advisory firm based in New Zealand. The project was aimed at answering the question 'How do the current engagement levels influence client retention at XY?' In particular, what communication methods are being used by $X Y$ to engage their clients, how satisfied the clients are with the amount of engagement and, whether there is a relationship between the amount of engagement and client retention.

Two research methods were used to gain a more in-depth understanding of the research problem. Online questionnaires were distributed to clients using $X Y$ services Interviews were conducted with eight manegers in the questionnaires were distributed to clients using XY services. Interviews were conducted with eight managers in the

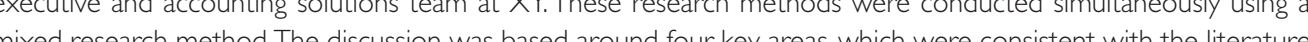
mixed research method. The discussion was based around four key areas, which were consistent with the literature
review and supported by academic literature.

In conclusion, there was only a moderate, and arguably vague, relationship found between the current engagement levels and retention of clients Instead clients appeared to have an adequate amount of communication In terms of communication methods, XY used emails, phone calls, face-to-face meetings and mailed letters to engage clients There was a so no retstion of the individual clients and other factors.

In summary, this research produced some interesting results, followed by a number of specific recommendations for $\mathrm{XY}$ and future basis in relation to research.

Le Wen Tran. Alumni Student, School of Business, Otago Polytechnic, Dunedin, NZ

Le Wen is an Otago Polytechnic Alumni Student and graduated as with a Bachelor of Applied Management in Accounting (Distinction) in 2018. During her studies, she received top student awards in Introduction to Finance and Accounting Information Systems in 2018. She works for an accounting consultancy firm in New Zealand.

Dr Ehtasham Ghauri. Lecturer, School of Business, Otago Polytechnic, Dunedin, NZ

Dr Ehtasham Ghauri is a lecturer in accounting at the Otago Polytechnic. Ehtasham has diverse experience in the industry and has published in internationally ranked journals about performance management, employee attitude and behaviour, social influence, diversity and sustainability.

\section{REFERENCES}

Abdalla, M., Oliveira, L. G. L., Azevedo, C. E. F., \& Gonzalez, R. K. (2018). Quality in qualitative organizational research: Types of triangulation as a methodological ate Akbari, M., Kazemi, R.\& \& Haddadi, M. (2016). Relationship marketing and word-of-mouth communications: Examining the mediating
role of customer loyalty Marketing and Branding Research, 3(1), 63-74, doithttp://dx.doi.org.op.idm.oclc.org//10.19237/ MBR.2016.01.06
MBR

Aljukhadar, M., \& Senecal, S. (2017). Communicating online information via streaming video: The role of user goal. Online Information
Review, 4 (3), 378-397. Retrieved from https://search-proquest-com.op.idm.oclc.org/docview/ 1902388839 ?accountid $=39660$ Bailey, C.A., (2018). A guide to qualitative field research. (3rd ed.). LA, USA: Sage.

Bose, S. and Rao,V.G. (20I I) Perceived benefits of customer loyalty programs:Validating the scale in the Indian context, Manogement \& Marketing Challenges for the Knowledge Society, 6(4), 543-560.

Brannen, J. (2005). Mixing methods: the entry of qualitative and quantitative approaches into the research process. International Journal of Social Research Methodology, 8(3), 173-184.

Brunner T.A, Stocklin M., Opwis K., (2008). Satisfaction, image and loyalty: new versus experienced customers, European Journal of Marketing, 42(9/10), 1095-1105 
Cameron, M. and Reeb, W. (2008). The fortress and the empire: a marketing strategy for the professional services firm, Southern Business Review, 33(2), I-12.

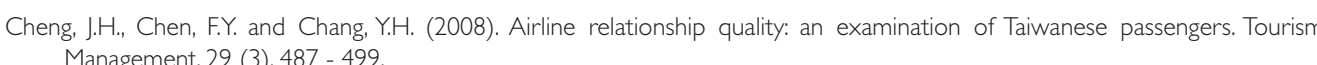

Dabholkar P.A. (2015). How to improve perceived service quality by increasing customer participation. In: Dunlap B. (eds) Proceedings of the 1990 Academy of Marketing Science (AMS) Annual Confer
Proceedings of the Academy of Marketing Science. Springer, Cham. 483-487.

Dadfar, H., Brege, S. \& Sedigheh Sarah, E. S. (2013). Customer involvement in service production, delivery and quality: The challenges and opportunities. International Journal of Quality and Service Sciences, $5(1)$, 46-65. doi:http://dx.doi.org.op.idm.ocle. org//|0.1108/1756669/3/1316248

Danaher, P.]., \& Rossiter, J.R. (2011). Comparing perceptions of marketing communication channels. European Journal of Marketing 45(1), 6-42. doi:http://dx.doi.org.op.idm.oclc.org/ /0. I 1 08/0309056 I I I 1095586

Eikeland, O. (2012). Action research - applied research, intervention research, collaborative research, practitioner research, or praxis research? International Journal of Action Research, 8(I), 9-44. Retrieved from https://search-proquest-com.opidm.ocl.org/doc

Grafton, J., Lillis, A. M., \& Mahama, H. (201 I). Mixed methods research in accounting. Qualitative Research in Accounting and

Hackshaw, A. (2008). Small studies: strengths and limitations. European Respiratory Journal. 32(5), I | 4 | - I 143.

Hannan, S., Suhario, B., Kirbrandoko, K., and Nurmalina, R. (2017). The influence of customer satisfaction, trust and information sharing on customer loyalty of professional services company: An empirical study on independent surveyor services industr Hayes, B.E. (2008). The true test of loyalty. Quality Progress, 4 I (6), $20-26$.

Jayawardhena, C., (2010). The impact of service encounter quality in service evaluation: evidence from a business-to-busines

Jones, M. (2010). Customer engagement and loyalty in financial services. Corporate Finance Review, 15(3), 25-29. Retrieved from

Karasz, H. N., Eiden, A., J.D., \& Bogan, S., M.P.H. (2013). Text messaging to communicate with public health audiences: How the HIPAA security rule affects prectic

Kaura, V., Ch, S. Prasad, D., and Sharma, S. (2015). Service quality, service convenience, price and fairness, customer loyalty, and the mediating role of customer satisfaction. The International Journal of Bank Marketing, 33(4), 404-422.

Keiningham, T., and Aksoy, L., (2009) When customer loyalty is a bad thing. Retrieved 8 August 20 18, from https://hbr.org/2009/05/ when-customer-loyalty-is-a-bad

Keiningham, T.L, Cooil, B., Aksoy, L, Andreassen, T.W, \& Weiner, J. (2007). The value of different customer satisfaction and loyalty metrics in predicting customer retention, recommendation, and share-of-wallet. Managing Service Quality, 17(4) 361-384.

Kishi, M. (2008). Perceptions and use of electronic media: Testing the relationship between organizational interpretation differences and media richness. Information \& Management, 45(5), 28I. Retrieved from https://search-proquest-com.op.idm.ock.org/doc view/237015275? accountid $=39660$

Kiwis Count. (2010). How New Zealanders are accessing services. Retrieved from http://wnw.ssc.govt.nz/node/35I8

Kumar, R., (20I I). Research methodology a step-by-step guide for beginners. (3rd ed.) United States of America, Los Angeles: Sage.

Laketa, M. Sanader, D., Laketa, L., \& Misic, Z. (2015). Customer relationship management: concept and importance for banking sector UTMS Journal of Economics, 6(2), 24l-254. Retrieved from https://search-proquest-com.op.idm.ocl.org/docview//8183548 2?accountid 39660

Lavrakas, P.. (2008). Gatekeeper. Retrieved from http://dx.doi.org// 0.4135/9781412963947.n200

Lee, Y., Kozar, K.A. and Larsen, KR, (2009). Avatar e-mail versus traditional e-mail: perceptual difference and media selection difference. Decision Support Systems, 46(2), 451 - 467.

McColl-Kennedy, J., Sweeney, J., Soutar, G. and Amonini, C. (2008). Professional service firms are relationship marketers: but does size matter? Australasian Marketing Journal, $16(1), 30-47$.

Merk-Davies, D., \& Brennan, N. M. (2017). A theoretical framework of external accounting communication. Accounting, Auditing \& Accountability Journal, 30(2), 433-469. doi:http://dx.doi.org.op.idm.oclc.org// 0.1 I 08/AAAJ-04-2015-2039

Merriam-Webster. (n.d.). Communication. Retrieved from https://wnw.merriam-webster.com/dictionary/communication

Nice Satmetrix (2017). What is net promoter? Retrieved from https://nww.netpromoter.com/know/
Nixon, R. (20II). Accounting practices don't add up! Why they don't and what to do about it. Fremantle, Western Australia: VIVID Publishing.

Pi, W.P. and Huang, H.H. (201 I). Effects of promotion on relationship quality and customer loyalty in the airline industry: The relationship marketing approach. African Journal of Business Management, $5(\mathrm{I} I), 4403-4414$.

Rehnen, L.M; Bartsch, S., Kull, M., and Meyer, A. (2017). Exploring the impact of rewarded social media engagement in loyalty programs. Journal of
3? accountid=39660

Roberts, C., and Alpert, F. (20|0).Total customer engagement: Designing and aligning key strategic elements to achieve growth. The Journal of Product and Brand Management, 19(3), 198-209. doi:http://dx.doi.org// $0.1108 / 10610421011046175$ Marketing, 28(8), 607-619. doi.http://dx.doi.org.op.idm.ock.org//0.1 1 08//BBM-03-201 I-0028

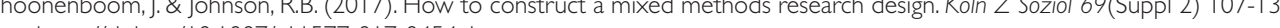
https://doi.org/ | 0.1 1007/s/ | 1577-017-0454-1

Shrivastava, S. (2012). Comprehensive modelling of communication barriers:A conceptual framework. IUP Journal of Soff Skills, 6(3), 7-19. Retrieved from https://search-proquest-com.op.idm.oclc.org/docview/ 1614146848 ?accountid=39660

Sinha, A. B. (2012). Business communication: The mainstay of an efficient business. IUPJ Journal of Soft Skills, $6(1)$ ) 7-15. Retrieved from hitps://search-proquest-com.opidm.ock.org//ocview/433289420!accountid=39660

Siriprasoetsin, P. Tuamsuk, K. and Vongprasert, C. (201 I). Factors affecting customer relationship management practices in Thai academic libraries. The International Information and Library Review, 43(4), 221-229.

Stan, V., Caemmerer, B., \& Cattan-Jallet, R. (2013). Customer loyalty development: The role of switching costs. Journal of Applied Business Research, 29(5), 154 I-n/a. Retrieved from https://search-proquest-com.op.idm.ockc.org/docview/ I 473895282?acc

Stone, G. (2012). The effectiveness of newsletters in accountants' client relations with small business managers. Qualitative Research

Stone, G. (201 I). Let's talk. Accounting, Auditing \& Accountability Journal, 24(6), 78I-809.

doi:http://dx.doi.org/ | 0.1 | I 08/095 I357| | I I I I55546

Szczepanska, K. and Gawron, P. P., (201 I). Changes in approach to customer loyalty. Contemporary Economics. 5( I I), 60-69. DOI:

Trasorras, R., Weinstein, A, \& Abratt, R. (2009).Value, satisfaction, loyalty and retention in professional services. Marketing Intelligence \& Planning, 27(5), 615-632. do:ihttp://dx.doi.org.op.idm.ockl.org/ / 0. I 1 08/02634500910977854

Tripathy, M. (2018). Assertiveness - A win-win approach to business communication. IUP Journal of Soft Skills, I2(2), 48-56. Retrieved

Van de Mortel, T.F., (2008). Faking it: social desirability response bias in self-report research. Australian Journal of Advanced Nursing,

Vivek, S.D; Beatty, S.E; Morgan, R.M (2012). Customer engagement: Exploring customer relationships beyond purchase. Journal of

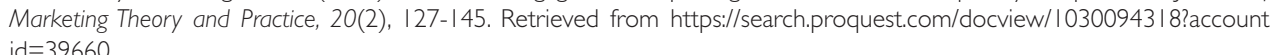

Walsh, K., and Gordon, I. R. (2010). Understanding professional service de
2(2).217-238. doilhtp:///dx.doi.org/10.1 $108 / 17566691011057375$

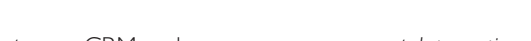
Wang, X.L. (20 12). Relationship or revenue: potential man
Journal of Hospitality Management 3/ (3).864-874

Wright, K. B. (2005). Researching Internet-based populations: Advantages and disadvantages of online survey research. Online burvey Services Jounnal of Computer-Mediated Communication 10(3).

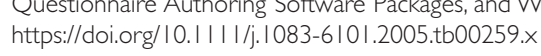

Zeithaml, V.A., Bitner, M.J., and Dwayne, D.G. (2009). Services marketing: Integrating customer focus across the Firm (5th ed). Boston: Mc. Graw Hill Irwin. 


\section{Client Engagement Survey}

Appendix B

Interview Questions

I. How long have you been working at $X Y$ ?

Client Engagement Survey

NOVEMBER 2018

2. How long have you been a manager here?

How many clients do you manage?

Do you deal with a specific service industry or a range of different industries?

5. Would you like to work with a specific or a range of industries?

6. What main services do you provide to your clients? Annual accounts, special work, monthly reports, taxation

7. What factors do you think drive client retention?

8. What do you think it means to engage with your clients?

9. Would you like to increase how much you engage with your clients?

10. Is there a specific communication channel you prefer to use when communicating with clients? Face to face, Email, Mail. Why

11. Is there a particular business industry that you noticed required more contact or would like more contact?

12. How valuable do you think it would be for $X Y$ to engage more with their clients?

13. How valuable would it be for the client to engage more with you?

14. Do you think engagement levels affect the retention of customers? How so?

\section{How many years have you been using PHs' services?}

Please select one

0-5 $\bigcirc$ 6-10 $\bigcirc 11-15 \bigcirc 15+$

2. What services, provided by PH, have you used? Select multiple boxes if required.

Annual Accounting

$\square$

Special work/Monthly reporting

$\square$

Hurman Resources

$\square$

Payroll Solutions

$\square$

Taxation

$\square$

Wealth Management

$\square$

Information Services

$\square$

Business Systems Solution

$\square$

Training includes webinars

$\square$ 
4. How important is the frequency of communication to you, when using PHs' services?

Please select one

$\bigcirc$ Not important $\bigcirc$ Slightly important $\bigcirc$ Moderately important $\bigcirc$ important $\bigcirc$ Very important

5. How offen has PH contacted you in the last year? Please answer for every method of communication.

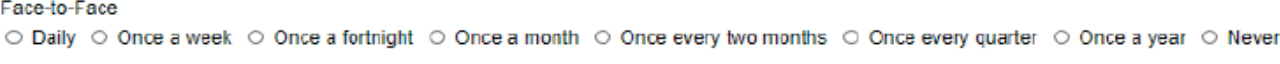
Phone call

$\bigcirc$ Daily $\bigcirc$ Once a week $\bigcirc$ Once a fortnight $\bigcirc$ Once a month $\bigcirc$ Once every two months $\bigcirc$ Once every quarter $\bigcirc$ Once a year $\bigcirc$ Never

$\circ$ Daily $\bigcirc$ Once a week $\bigcirc$ Once a fortright $\bigcirc$ Once a month $\bigcirc$ Once every two months $\odot$ Once every quarter $\bigcirc$ Once a year $\bigcirc$ Never Mailed letter

$\bigcirc$ Daliy $\bigcirc$ Once a week $\bigcirc$ Once a fortnight $\bigcirc$ Once a month $\bigcirc$ Once every two months $\bigcirc$ Once every quarter $\bigcirc$ Once a year $\bigcirc$ Never

Text messape

Daily $\bigcirc$ Once a weok $\bigcirc$ Once a fortright $\bigcirc$ Once a month $\bigcirc$ Once every two months $\bigcirc$ Once every quatter $\bigcirc$ Once a year $\bigcirc$ Never Video call

Daily $\bigcirc$ One a week $\bigcirc$ Once a fortright $\bigcirc$ Once a month $\bigcirc$ Once every two months $\bigcirc$ Once every quarter $\bigcirc$ Once a year $\bigcirc$ Never

\section{How often have you as a client, contacted PH in the last year? Please answer for every method of}

communication.

Face-to-Face

Once a week $\bigcirc$ Once a forthight $\bigcirc$ One a month $\bigcirc$ Once every two months $\bigcirc$ Once every quarter $\bigcirc$ Once a year $\bigcirc$ Never

Dalily $\bigcirc$ Once a week $\bigcirc$ Once a fortnight $\bigcirc$ Once a month $\bigcirc$ Once every two months $\bigcirc$ Once every quarter $\bigcirc$ Once a year $\bigcirc$ Never

$\circ$ Dally $\bigcirc$ Once a week $\bigcirc$ Once a tortnight $\bigcirc$ Once a month $\bigcirc$ Once every two moniths $\bigcirc$ Once every quarter $\bigcirc$ Once a year $\bigcirc$ Never Mailed letter

Dally $\bigcirc$ once a week $\bigcirc$ Once a tortngnt $\bigcirc$ Once a month $\bigcirc$ once every two months $\bigcirc$ once every quarter $\bigcirc$ Once a year $\bigcirc$ Never Text message

$\checkmark$ Dally $\bigcirc$ Once a week $\bigcirc$ Once a tornignt $\bigcirc$ Once a month $\bigcirc$ Once every two monnins $\bigcirc$ Once every quarter $\bigcirc$ Once a year $\bigcirc$ Never Video call

\section{Rate how more communication could improve the quality of service} you receive from $\mathrm{PH}$.

Select one option

$\bigcirc$ Not at all $\bigcirc$ A little $\bigcirc$ A moderate amount $\bigcirc$ A lot $\bigcirc$ A great deal
8. Please mention your level of preference for the following communication methods:

Face-to-Face

not profarrad
0102

Email

I=not profarred $5=$ most proforrad
$0102 \bigcirc 3 \circ 4 \circ 5$

Phone call

$\begin{array}{ll}1=\text { not preforred } & 5=\text { most preforrad } \\ 0102 & 103 \bigcirc 4 \bigcirc 5\end{array}$

Mailed letter

$5=$ most proforrad

Text message

$=$ not proferred
$01 \bigcirc 2$ $\begin{aligned} & 5=\text { most preforred } \\ & 0\end{aligned}$

Video call

$1=$ not prefarred
0102
1030 most preforred 


\section{Taking into account your whole experience with $\mathrm{PH}$, how} would you rate:

Quality of communication

Not understandable Very understandable

$$
\bigcirc 1 \bigcirc 2 \bigcirc 3 \bigcirc 4 \bigcirc 5
$$

Frequency of communication

$$
\text { Not enough Too much }
$$$$
\bigcirc 1 \bigcirc 2 \bigcirc 3 \bigcirc 4 \bigcirc 5
$$

Service standards

$$
\text { Low quality High quality }
$$$$
\bigcirc 1 \bigcirc 2 \bigcirc 3 \bigcirc 4 \bigcirc 5
$$

\section{How well has PH met your expectations as a client?}

\section{Expectations}

I=Failed to meet expectations $5=$ =Greatly exceeded expectations

$$
\bigcirc 1 \bigcirc 2 \bigcirc 3 \bigcirc 4 \bigcirc 5
$$

\section{How likely are you to continue using PH's services?}

Please select one

Oefintely will not be using them $\bigcirc$ Probably will not be using them $\bigcirc$ May or may not be using them $\bigcirc$ Probabbly will be using them $\bigcirc$ Defintely will be using them

\section{Recommendation. Please choose one}

On a scale of $0-10$, how likely are you to recommend $\mathrm{PH}$ to friends and colleagues?

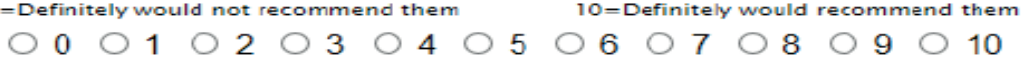

13. Have you any other comments or feedback? Comment here:

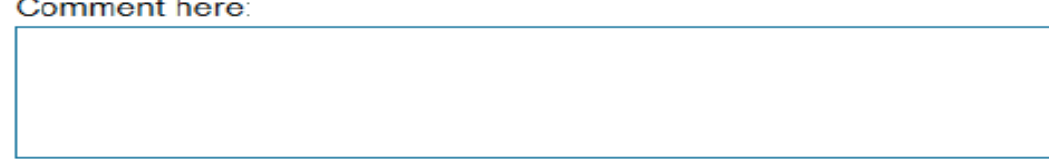

